\title{
Macrogeographic and fine-scale genetic structure in a North American oak species, Quercus rubra L
}

\author{
VL Sork, S Huang, E Wiener \\ Department of Biology, University of Missouri-St Louis, St Louis, MO, 63121-4499, USA
}

\begin{abstract}
Summary - Northern red oak, Quercus rubra L, is a widely distributed forest-dominant tree in North America. In this paper, we present the results of 2 studies examining macrogeographic and finescale genetic structure in the North American oak species Quercus rubra L. The first study used allozymes as genetic markers to examine the distribution of genetic variation within and among 10 widely distributed populations in midwestern USA. Our results revealed a high level of genetic variability within the species and a moderate level of genetic differentiation among 10 populations sampled $\left(F_{\mathrm{st}}\right.$ $=0.092$ ). In the second study, we evaluated fine-scale genetic structure of northern red oak in a single forest site in Missouri, USA. First, we used F-statistics to determine whether subpopulations in adjacent microhabitats on the scale of 1 ha show genetic differentiation within a 4-ha plot. Our findings showed very low values of differentiation $\left(F_{\text {st }}=0.011\right)$. However, we also used a statistical technique called spatial autocorrelation analysis to evaluate the spatial dispersion of alleles within a 4-ha mapped plot. These analyses revealed that genetic structure exists on a much smaller scale. Using 3 different algorithms, we found that near-neighbors have significant spatial autocorrelation which suggests that family structure occurs within the study population.
\end{abstract}

population genetic structure / genetic variation / genetic differentiation / isozymes / spatial autocorrelation / Quercus rubra

\begin{abstract}
Résumé - Structure génétique du chêne rouge d'Amérique à l'échelle géographique et à celle du peuplement. Le chêne rouge d'Amérique ( $Q$ rubra $L$ ) est une espèce très répandue en Amérique du Nord. Cette contribution présente les résultats d'une analyse de la structure génétique de cette espèce faite à l'échelle géographique et du peuplement. La première partie concerne l'étude de l'organisation de la diversité génétique faite à partir de 10 populations éloignées les unes des autres et issues du Midwest des États-Unis et basée sur les isozymes. Les résultats ont montré une diversité génétique élevée à l'intérieur de l'espèce et une différenciation génétique moyenne entre les 10 populations étudiées $\left(F_{s t}=0,092\right)$. Dans la seconde partie, l'étude a porté sur la structure génétique à l'intérieur d'un peuplement donné situé dans une forêt de l'État de Missouri (ÉtatsUnis). Tout d'abord les $\mathrm{F}$ statistiques ont été utilisées pour estimer le niveau de différenciation entre sous- populations d'une surface d'un ha, l'ensemble couvrant une surface de 4 ha. Les résultats ont montré que ce niveau restait faible $\left(\mathrm{F}_{s t}=0,011\right)$. Dans un second temps, les techniques d'autocorrélation spatiale ont révélé que la population était génétiquement structurée à une échelle plus fine. L'utilisation de 3 algorithmes différents a montré que les proches voisins au sein du peuplement sont génétiquement liés, indiquant qu'une structure familiale existe au sein de la population.
\end{abstract}

structure génétique / variabilité génétique / différenciation génétique / isozymes / autocorrélation spatiale / Quercus rubra 


\section{INTRODUCTION}

The distribution of genetic variability in a species is the outcome of gene flow, natural and artificial selection and genetic drift. Among wind-pollinated tree species, we expect widespread gene flow within and among populations (Loveless and Hamrick, 1984) and opportunities for genetic drift to be minimal. However, population differentiation and subdivision will occur if either pollen or seed dispersal is restricted or natural selection on a local scale is strong (Slatkin, 1973; Endler, 1977). Populations which occur in heterogeneous environments may be susceptible to locally varying selection pressures which could cause genetic subdivision of local populations (Wright, 1943). The extent to which population subdivision occurs in tree populations is valuable to know because the spatial scale of genetic differentiation may influence the evolutionary dynamics of the populations.

Northern red oak, Quercus rubra $\mathrm{L}$, is a major forest-dominant tree species in North American deciduous forests (Braun, 1950). It is widely-distributed, ranging from southern Quebec and Ontario south to northern Florida, and from the eastern edges of Texas, Oklahoma and Kansas up through lowa east to southeastern Minnesota (Schopmeyer, 1974). In this paper, we present the results of 2 studies examining macrogeographic and fine-scale genetic structure in the North American oak species $Q$ rubra $\mathrm{L}$. The first study used allozymes as genetic markers to examine the distribution of genetic variation within and among 10 widely distributed populations. A frequently-used method of describing genetic structure is hierarchical $F$ statistics analysis (Wright, 1951, 1965). These statistics describe the extent to which genetic variation is distributed within the total population $\left(F_{i t}\right)$, among subpopu- lations $\left(F_{\mathrm{st}}\right)$ and among individuals within subpopulations $\left(F_{\text {is }}\right) . F_{\mathrm{st}}$ or $G_{\mathrm{st}}$, a similar index derived by Nei (1973), provide a measure of genetic differentiation among subpopulations.

In the second study, we evaluated finescale genetic structure of northern and oak in a single forest site in Missouri, USA. First, we examined genetic structure within a location among adjacent subpopulations of $Q$ rubra using $F$-statistics. If such structure exists, it suggests that differential selection may be responsible because gene flow is not likely to be restricted in this wind-pollinated species (Sork, unpublished data). Because $F$-statistics are not always sensitive enough to detect patterns of genetic patchiness, especially within the subpopulation (Heywood, 1991), we also used spatial autocorrelation statistics. These have been proposed as a means of identifying the scale of genetic structure without prior knowledge about that scale (Sokal and Oden, 1978; Epperson and Clegg, 1986; but see Slatkin and Arter, 1991).

\section{MATERIALS AND METHODS}

The sampling sites for the macrogeographical study were 10 locations situated in the midwestern United States (fig 1, table I). These sites include northern, southern and western limits of the distribution of $Q$ rubra. During June and July of 1990 and 1991, we collected leaf tissue from 25 adults at each location. Individual trees sampled were $>10 \mathrm{~m}$ apart.

The intensive study site for the study of finescale genetic structure was located at Tyson Research Center, St Louis County, Missouri, USA, an 800-ha ecological reserve administered by Washington University. Tyson $\left(38^{\circ} 31^{\prime} \mathrm{N}\right.$, $90^{\circ} 33^{\prime} \mathrm{W}$ ) is located on the northeastern end of the Ozark Plateau. The oak-hickory forest at Tyson comprises approximately 600 ha and is contiguous with approximately 2000 ha of forest on adjacent public and privately-owned property. Within the study site was located a 4-ha plot of 
oak-hickory forest which had been permanently gridded into $20 \mathrm{~m} \times 20 \mathrm{~m}$ quadrants with all individual trees with breast height diameter $(D B H)>$ $2.5 \mathrm{~cm}$ labeled and mapped (Hampe, 1984) This plot included 4 microhabitats: north-facing slope which had the greatest inclination (mean = $20^{\circ}$, range $=15^{\circ}-30^{\circ}$ ); southwest-facing (mean $=15^{\circ}$, range $\left.=12-18^{\circ}\right) ;$ and west-facing slope with intermediate inclination (mean $=13^{\circ}$, range $=10-15^{\circ}$ ) which we divided into lower westfacing slope and upper west-facing slope. During the summer of 1990 , we collected leaf samples from all red oak adult trees $(n=226)$ on this plot with $D B H>20 \mathrm{~cm}$.

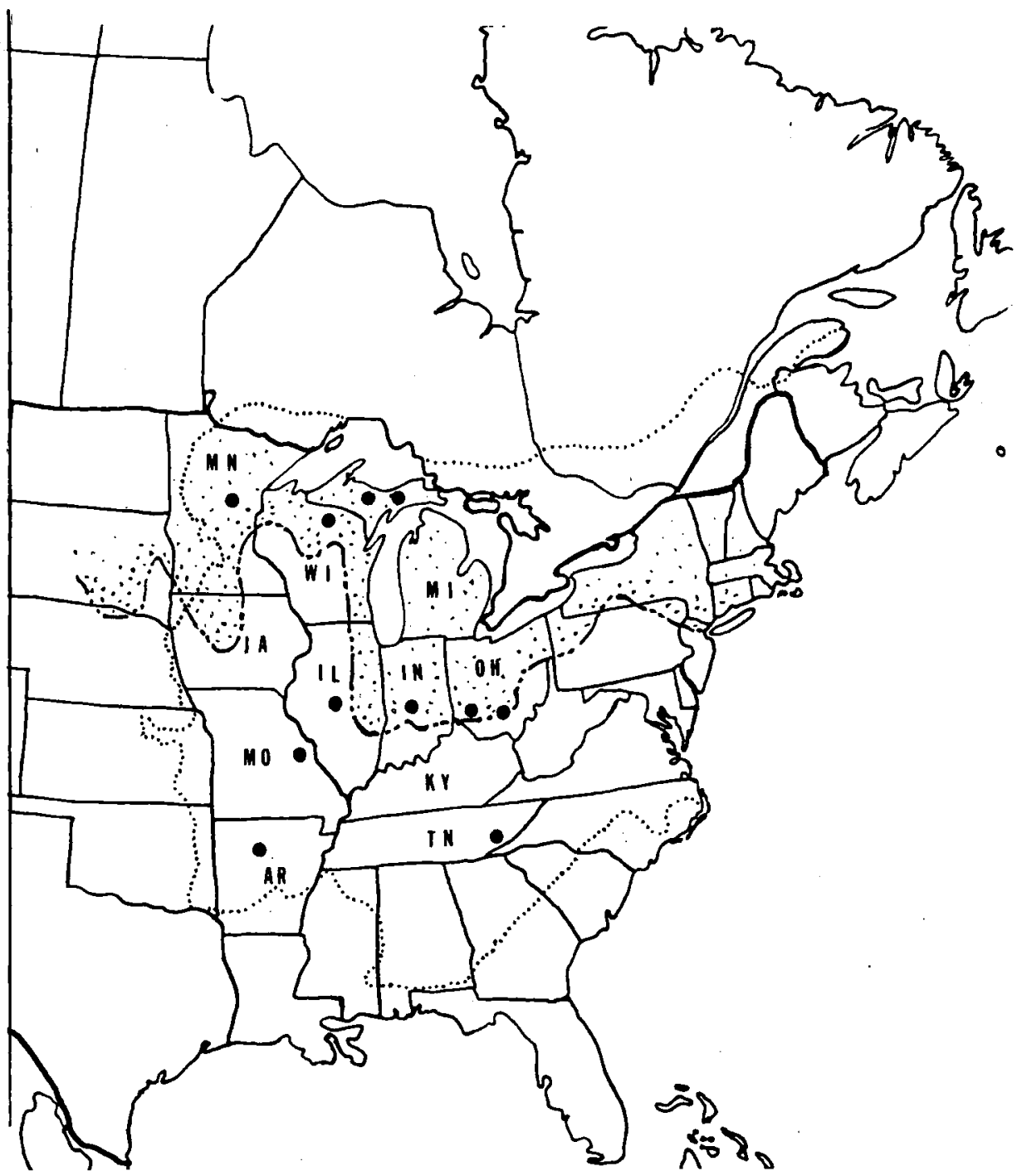

Fig 1. Map of eastern United States and Canada labeled with study populations of Quercus rubra. The dotted line indicates the limits of its range of distribution. The dashed line with dotted area above shows the area of the most recent glaciation, the Wisconsin. 
Table I. Genetic variability measures for 10 populations of Quercus rubra based on 15 isozyme loci.

\begin{tabular}{|c|c|c|c|c|c|c|c|}
\hline \multirow{2}{*}{$\begin{array}{l}\text { Nearest city, state } \\
\text { Russelville, AR }\end{array}$} & \multirow{2}{*}{ 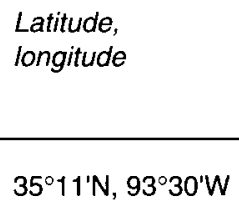 } & \multirow{2}{*}{$\begin{array}{l}\text { Mean } \\
\text { sample size } \\
\text { per locus }\end{array}$} & \multicolumn{2}{|c|}{$\begin{array}{l}\text { Alleles/locus } \\
\text { mean (SE) }\end{array}$} & $\begin{array}{c}\text { Polymorphic } \\
\text { index } \% \text { a }\end{array}$ & \multicolumn{2}{|c|}{$\begin{array}{l}\text { Heterozygosity b } \\
\text { Mean (SE) }\end{array}$} \\
\hline & & & 2.3 & $(0.4)$ & 41.7 & 0.196 & $(0.196)$ \\
\hline Knoxville, TN & $35^{\circ} 35^{\prime} \mathrm{N}, 84^{\circ} 00^{\prime} \mathrm{W}$ & 24.7 & 2.3 & $(0.4)$ & 50.0 & 0.167 & $(0.062)$ \\
\hline Indianapolis, IN & $39^{\circ} 15^{\prime} \mathrm{N}, 86^{\circ} 15^{\prime} \mathrm{W}$ & 20.8 & 2.3 & (0.3) & 58.3 & 0.191 & (0.058) \\
\hline Colombus, $\mathrm{OH}$ & $39^{\circ} 30^{\prime} \mathrm{N}, 83^{\circ} 30^{\prime} \mathrm{W}$ & 19.9 & 2.1 & (0.3) & 58.3 & 0.145 & $(0.059)$ \\
\hline Springfield, IL & $39^{\circ} 40^{\prime} \mathrm{N}, 89^{\circ} 39^{\prime} \mathrm{W}$ & 25.0 & 2.0 & (0.3) & 50.0 & 0.179 & (0.059) \\
\hline Lima, $\mathrm{OH}$ & $40^{\circ} 15^{\prime} \mathrm{N}, 86^{\circ} 15^{\prime} \mathrm{W}$ & 24.0 & 1.8 & $(0.2)$ & 50.0 & 0.165 & $(0.057)$ \\
\hline Wausau, WI & $46^{\circ} 00^{\prime} \mathrm{N}, 89^{\circ} 00^{\prime} \mathrm{W}$ & 24.6 & 2.1 & $(0.3)$ & 50.0 & 0.199 & $(0.074)$ \\
\hline Duluth, MN & $46^{\circ} 00^{\prime} \mathrm{N}, 92^{\circ} 45^{\prime} \mathrm{W}$ & 20.8 & 2.0 & $(0.3)$ & 58.3 & 0.245 & $(0.073)$ \\
\hline Manistique, MI & $46^{\circ} 15^{\prime} \mathrm{N}, 86^{\circ} 30^{\prime} \mathrm{W}$ & 24.9 & 2.0 & $(0.3)$ & 46.7 & 0.197 & $(0.062)$ \\
\hline Marquette, MI & $46^{\circ} 30^{\prime} \mathrm{N}, 87^{\circ} 00^{\prime} \mathrm{W}$ & 24.9 & 1.9 & (0.3) & 33.3 & 0.178 & $(0.070)$ \\
\hline
\end{tabular}

\footnotetext{
${ }^{a}$ A locus is considered polymorphic if the frequency of the most common allele does not exceed 0.95 .

b Unbiased estimate (see Nei, 1978).
}

For both studies, leaves were collected from each individual with clipper poles, shot gun or sling shot and then kept on ice until transported back to the laboratory. Leaves were stored at $-75^{\circ} \mathrm{C}$ until ready for electrophoretic analysis. Starch-gels were run following the techniques of Gottlieb (1981) and Soltis et al (1983) using a phosphate extraction buffer (Mitton et al, 1977), modified to $10 \%$ polyvinylpyrrolidone (Manos and Fairbrothers, 1987). The recipes for all enzymes were modified from Soltis et al (1983). We used buffer system 1 from Soltis et al (1983) to detect 6-phosphogluconic dehydrogenase (6PGD, EC 1.1.1.44), shikimate dehydrogenase (SDH, EC 1.1.1.25), phosphoglucomutase (PGM, EC 5.4.2.2), isocitrate dehydrogenase (IDH, EC 1.1.1.42) and malate dehydrogenase (MDH, EC 1.1.1.37). Buffer system 2 (Soltis et al, 1983) was used for peroxidase (PER, EC 1.11.1.7). Buffer system 6 (Soltis et al, 1983) was used for phosphoglucoisomerase (PGI, EC 5.3.1.9), triose-phosphate isomerase (TPI, EC 5.3.1.1), and acid phosphatase (ACPH, EC 3.1.3.2). Buffer system 8 (Haufler, 1985) was used for fluorescent esterase (FES, EC 3.1.1-) and leucine- amino-peptidase (LAP, EC 3.4.11.1). All these enzymes have shown inheritance patterns consistent with an interpretation of Mendelian inheritance.
The F-statistics and genetic descriptive statistics for the 10 widely distributed populations and the 4 subpopulations within the intensive study plot were calculated using the program, BIOSYS-1 (Swolford and Selander, 1981). We used 15 loci for the macrogeographic analysis of genetic diversity and 11 polymorphic loci $(0.99$ level) for the estimation of $F$-statistics for both studies. For the spatial autocorrelation (SA) analysis of $Q$ rubra, we selected the 3 most variable isozyme loci. The SA analysis was done using the program of Heywood (Dewey and Heywood, 1988). This program uses allozyme variation to calculate Moran's I, a coefficient of spatial autocorrelation (Sokal and Oden, 1978), which varies between +1 (complete positive autocorrelation) and -1 (complete negative autocorrelation) for any comparison of 2 individuals. We used 3 methods to calculate Moran's $t$ : nearest-neighbor maps which compare only 2 individuals, Gabriel-connected maps which compare several neighboring individuals, and correlograms which examine all pairs of individuals within a specified distance class as a function of distance class. This latter method provides insight about the scale of genetic structure if it exists within the distance classes examined (for a more detailed description of these methods, see Sokal and Oden, 1978). 


\section{RESULTS AND DISCUSSION}

\section{Macrogeographic genetic structure}

Individual populations of $Q$ rubra maintain relatively high levels of genetic variation (table 1). We found that the average percent polymorphism across populations was $43 \%$, the average number of alleles/locus was close to 2 (mean $=1.97$ ), and the mean heterozygosity ranged between 0.136 and 0.231 with a mean of 0.167 . We caution that these data may be biased upward because we selected loci that are likely to be polymorphic. At the species level, we observed 3.19 alleles/locus with $94.1 \%$ showing some level of polymorphism in at least 1 population.

Our estimate of 0.167 average heterozygosity is less than a mean value of 0.270 reported for a sample of 11 studies of conifer species (Mitton, 1983). However, our values are similar to those found in $Q$ gam- belii and $Q$ macrocarpa (Schnabel and Hamrick, 1990a) and 18 other North American oak species (Guttman and Weigt, 1989). In contrast, a mean heterozygosity of 0.081 was observed for 7 species of oaks in New Jersey, USA (Manos and Fairbrothers, 1987) but this area sampled is much smaller than that tested in other studies.

The 10 populations surveyed showed a moderate degree of genetic differentiation based on the analysis of 11 polymorphic loci (overall $F_{\mathrm{st}}=0.092$, table II). This estimate of genetic differentiation among populations is at the high end of the range of values expected for wind-pollinated, longlived woody species $\left(G_{\mathrm{st}}=0.07-0.09\right.$; Hamrick and Godt, 1989) and in the middle of the range of $G_{\mathrm{st}}$ values summarized for conifer species by El-Kassaby (1990), who reported a ranged of $G_{\mathrm{st}}$ values from 0 to $16.2 \%$ from 54 studies. However, our estimate of $F_{\mathrm{st}}$ is similar to that Schnabel and Hamrick (1990a) measured $\left(G_{s t}=0.076\right.$

Table II. Summary of F-statistics across 10 subpopulations of Quercus rubra occurring throughout midwestern USA (see fig 1 for locations) and across 4 microhabitats within 1 location in Missouri, USA. Analyses are based on 11 polymorphic loci for sets of analyses. Arithmetic means of the $F$ values are given.

\begin{tabular}{|c|c|c|c|c|c|c|}
\hline \multirow[t]{2}{*}{ Locus } & \multicolumn{3}{|c|}{ Across midwestern USA } & \multicolumn{3}{|c|}{ Across adjacent subpopulation } \\
\hline & $\mathrm{F}_{I S}$ & $F_{I T}$ & $\mathrm{~F}_{S T}$ & $\mathrm{~F}_{I S}$ & $\mathrm{~F}_{/ T}$ & $F_{1 T}$ \\
\hline PGI-1 & 0.650 & 0.665 & 0.042 & -0.006 & 0.002 & 0.005 \\
\hline PGI-2 & 0.070 & 0.232 & 0.174 & -0.015 & 0.010 & 0.025 \\
\hline TPI-1 & -0.023 & -0.004 & 0.018 & -0.012 & -0.003 & 0.009 \\
\hline PGM-2 & -0.056 & 0.090 & 0.138 & -0.036 & -0.031 & 0.005 \\
\hline IDH & 0.040 & 0.085 & 0.046 & -0.060 & -0.055 & 0.005 \\
\hline 6-PGD & 0.196 & 0.234 & 0.047 & -0.052 & -0.028 & 0.023 \\
\hline $\mathrm{SDH}$ & -0.054 & 0.036 & 0.085 & 0.023 & 0.024 & 0.001 \\
\hline FEST-1 & -0.050 & -0.043 & 0.007 & -0.029 & -0.027 & 0.002 \\
\hline FEST-2 & -0.091 & -0.064 & 0.025 & -0.077 & -0.062 & 0.013 \\
\hline LAP & 0.568 & 0.592 & 0.055 & 0.061 & 0.080 & 0.020 \\
\hline PER-1 & 0.180 & 0.243 & 0.077 & 0.270 & 0.282 & 0.017 \\
\hline Mean & 0.100 & 0.183 & 0.092 & 0.067 & 0.077 & 0.011 \\
\hline
\end{tabular}


for 19 populations of $Q$ macrocarpa and $G_{\mathrm{st}}=0.11$ for 18 populations of $Q$ gambeiii), but higher than that observed for 8 populations of $Q$ rubra in Pennsylvania, USA (Schwarzmann and Gerrold, 1991). The pattern of genetic differentiation that we observed in $Q$ rubra is likely to be due to a combination of factors. Because northern red oak occupies a great latitudinal range, natural selection due to environmental factors associated with that gradient may influence population differentiation. In addition, because of the glacial history of midwestern United States, bottleneck effects, genetic drift and uneven migration patterns may all contribute to a high degree of genetic differentiation (Schlarbaum et al, 1982).

\section{Fine-scale genetic structure}

The pattern of genetic variation based on 11 polymorphic loci measured on individual adults within the intensive study plot in Missouri is relatively high (table III) and quite comparable to the values reported for the macrogeographic survey (table I). Moreover, even within the microhabitats which are in the order of 1 ha in area, northern red oak maintains a large amount of variation. Although the microhabitats have unequal sample sizes (see table III), the general conclusions from these data should not be biased. That is, on every spatial scale-microhabitat, location and species, northern red oak has moderately high allelic diversity and heterozygosity.

We analyzed the genetic structure of our intensive study site and found that the amount of genetic differentiation across 4 microhabitats is extremely low $\left(F_{\mathrm{st}}=\right.$ 0.011 , table II). This low estimate is consistent across all 11 loci, suggesting that selection or some other factor has not acted on any of the individual loci. Thus, for this population, the hypothesis that isozyme loci are neutral may be valid. The average fixation index is also low ( $F_{\text {is }}=$ $0.067)$ which suggests that the adult subpopulations are not inbred. This value is slightly lower than the average level observed across populations ( $F_{\text {is }}=0.10$, table II).

Our finding that genetic differentiation across adjacent microhabitats is extremely low indicates that little population subdivision has occurred on this scale. However, this result contrasts with findings from a reciprocal transplant experiment at the same study site where we found evidence for local adaptation in seedling populations (Sork et al, in press). In that study, a reciprocal transplant experiment utilizing acorns from maternal parents living in each microhabitat revealed that percent leaf damage by insect herbivores was lower on seed-

Table III. Genetic variability measures based on 11 polymorphic loci and mean sample size for 4 subpopulations of Quercus rubra located in adjacent microhabitats within a 4-ha plot in an oakhickory forest in Missouri, USA. Microhabitat types are upper-west facing slope (UW), lowerwest facing slope (LW), north-facing slope (NO) and southwestern facing slope (SW).

\begin{tabular}{lcccc}
\hline Parameter & UW & LW & NO & SW \\
\hline $\begin{array}{l}\text { Mean sample } \\
\text { sizes }\end{array}$ & 36.5 & 45.7 & 81.3 & 53.9 \\
$\begin{array}{l}\text { Mean } \\
\text { alleles/locus }\end{array}$ & 2.27 & 2.45 & 2.82 & 2.36 \\
$\begin{array}{l}\text { Polymorphic } \\
\text { index (\%) }\end{array}$ & 54.6 & 63.6 & 72.7 & 54.5 \\
$\begin{array}{l}\text { Mean } \\
\text { heterozygosity }\end{array}$ & 0.182 & 0.213 & 0.214 & 0.198 \\
\hline
\end{tabular}

a locus is considered polymorphic if the frequency of the most common allele does not exceed 0.95 . ${ }^{b}$ Unbiased estimate (see Nei, 1978). 
lings grown in the maternal microhabitat. Consequently, the set of isozyme genetic markers as measured on the adult population in this study area seems neutral with respect to the selection of characters related to resistance to herbivores. This result indicates that quantitative characters which are related to seedling performance may show significantly different patterns of genetic differentiaton than isozyme genetic markers.

Our additional analysis of fine-scale genetic structure using spatial autocorrelation analysis on 3 loci (table IV) suggests that structure may exist on a scale smaller than the microhabitat. We found that PER-1 and FEST-2 had positive SA for both the Gabriel-connected map and the nearestneighbor map at all 6 alleles (table IV). Moreover, Moran's / was significantly greater than 0 for 2 alleles of PER- 1 using the Gabriel-connected map and 1 allele of PER-1 and 2 alleles of FEST-2 using the nearest-neighbor map. Although the Gabriel-connected map provides a more powerful test of SA due to the greater number of connections (Dewey and Heywood, 1988), both algorithms demonstrate a pattern of spatial autocorrelation. The 2 different methods yield slightly different mean distances of nearest-neighbors with the Gabrielconnected map having a larger radius than the nearest-neighbor map (table V). However, the scale of these differences is similar.

The correlogram suggests positive autocorrelation for the $5 \mathrm{~m}$ distance class which was significant $(P<0.05)$ for the FEST-2 and PER-1 loci (fig 2). Because this first distance class is the most likely one to reveal autocorrelation if there is isolation by distance, we only used this class to test for significance from zero. After that distance class, the values vary around zero with an occasional value occurring much higher or lower but no clear pattern resulting. Consequently, we conclude that the correlogram demonstrates a pattern of high relatedness among near-neighbors which is consistent with previous analyses based on Gabriel-connected and nearestneighbor maps but random fluctuations after that distance.

Table IV. The coefficient of spatial autocorrelation (Moran's I) based on ranks, its standard deviation (SD) and the standard normal deviate (SND) testing the null hypothesis $I=0\left(^{*}=P<0.05\right)$. The results are presented for 2 methods of pairing individuals along with the mean distance between pairs for each allozyme. Lower case letters indicate alleles.

\begin{tabular}{|c|c|c|c|c|c|c|c|c|}
\hline \multirow[t]{2}{*}{ Allele } & \multicolumn{4}{|c|}{ Gabriel-connected map } & \multicolumn{4}{|c|}{ Nearest-neighbor map } \\
\hline & $I$ & $S D$ & $S N D$ & $\begin{array}{l}\text { Mean } \\
\text { distance } \\
\text { (m) }\end{array}$ & 1 & $S D$ & $S N D$ & $\begin{array}{c}\text { Mean } \\
\text { distance } \\
(m)\end{array}$ \\
\hline PER-1a & 0.039 & 0.0512 & 0.845 & 10.5 & 0.180 & 0.0813 & $2.271^{*}$ & 6.0 \\
\hline PER-1b & 0.143 & 0.0512 & $2.878^{*}$ & & 0.146 & 0.0813 & 1.859 & \\
\hline PER-1C & 0.050 & 0.0512 & 1.180 & & 0.095 & 0.0813 & 1.229 & \\
\hline PER-1d & 0.098 & 0.0512 & $2.006^{*}$ & & 0.124 & 0.0813 & 1.583 & \\
\hline FES-2a & 0.054 & 0.0515 & 1.143 & 10.5 & 0.179 & 0.0827 & $2.218^{*}$ & 5.79 \\
\hline FES- $2 \mathrm{~b}$ & 0.040 & 0.0515 & 0.858 & & 0.163 & 0.0827 & $2.033^{*}$ & \\
\hline $\mathrm{SDH}-1 \mathrm{a}$ & -0.116 & 0.0505 & $-2.222^{*}$ & 10.1 & -0.099 & 0.0790 & -1.206 & 5.70 \\
\hline $\mathrm{SDH}-1 \mathrm{~b}$ & 0.010 & 0.0505 & 0.289 & & 0.047 & 0.0790 & 0.651 & \\
\hline $\mathrm{SDH}-1 \mathrm{C}$ & -0.030 & 0.0505 & -0.509 & & 0.003 & 0.0790 & 0.097 & \\
\hline
\end{tabular}




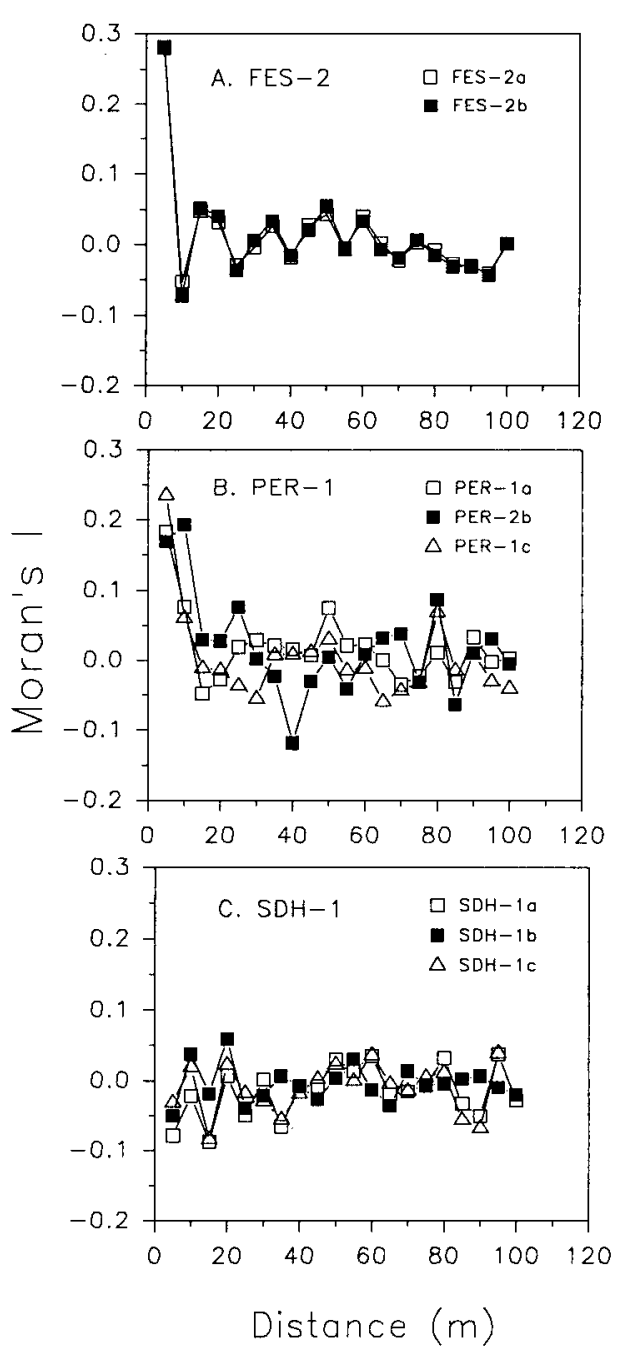

Fig 2. Moran's $/$ as a function of distance class for alleles at 3 isozyme loci, FEST-2 (A), PER-1 (B) and SDH-1 (C). The $X$-axis value indicates the maximum value in that distance class; lower case letters indicate alleles.

In contrast to this pattern of nearneighbor autocorrelation, SDH showed a significant negative SA at 1 of the 3 allozymes using a Gabriel-connected map and none of the allozymes using the nearest-neighbor map (table IV). This pattern was not significant in the correlogram (fig 2) where all 3 alleles at the $5 \mathrm{~m}$ distance class have slightly negative values of Moran's $I$. This result is too weak to determine whether selection or disassortative mating is acting on the $\mathrm{SDH}_{1}{ }^{\text {a }}$ allele or whether the correlation is spurious.

While it is not easy to infer mechanisms from spatial autocorrelation analyses (Slatkin and Arter, 1991), we suggest that this pattern is more likely due to restricted gene dispersal than spatially variable selection. Because we know that $Q$ rubra in this population and elsewhere (Schwartzmann and Gerhold, 1991; Sork et al, 1992) has high outcrossing rates, it is unlikely that pollen dispersal is restricted to the scale of $5 \mathrm{~m}$. However, seed dispersal by mammals is restricted and often results in dispersal distances of less than $10 \mathrm{~m}$ (Sork, 1984).

While it is also possible that acorns may be dispersed by birds at greater distances, if a large proportion of the acorn crop falls beneath the canopy or is removed only short distances by mammals, local family clusters may result. The spatial autocorrelation observed in this study is consistent with that scenario. Family clusters resulting from restricted seed dispersal have also been proposed for ponderosa pine (Linhart et al, 1981).

Our finding of significant spatial autocorrelation is similar to that found in Gleditsia triacanthos where the occurrence of significant autocorrelation at several loci for sampled juveniles indicates genetic substructuring that also might be due to family clusters (Schnabel and Hamrick, 1990b). In contrast, a study of Pinus contorta where individuals were sampled at $15-\mathrm{m}$ intervals in 2 Washington, USA populations (Epperson and Allard, 1989) reported little autocorrealtion except for a few loci. Those authors concluded that long dis- 
tance pollen and seed dispersal reduces the opportunity for genetic structure but selection may be affecting the genotypes at those significant loci. The Pinus results may differ from our oak results because dispersal of pine seeds differs dramatically from acorns. Until we see a broader range of studies which evaluates the genetic structure within tree populations, we cannot determine the extent to which this component of genetic variation is important.

\section{ACKNOWLEDGMENTS}

We thank AM Escalante and G Coello for considerable help with the electrophoresis; $M$ Cecil and A Klemm for help in the laboratory; and K Stowe, J Frazee, N Schellhorne, and C Hochwender for field assistance. We are grateful to J Hamrick and $J$ Heywood for comments on this manuscripts. This project is supported by a National Science Foundation grant (BSR-8814620) to VLS.

\section{REFERENCES}

Braun L (1950) Deciduous Forests of Eastern North America. McGraw-Hill, New York, USA

Dewey SE, Heywood JH (1988) Spatial genetic structure in a population of Psychotria nervosa. I. Distribution of genotypes. Evolution 42, 834-838

El-Kassaby YA (1990) Genetic variation within and among conifer populations: review and evaluations of methods. in: Biochemical Markers in the Population Genetics of Forest Trees (Hattemer HH, Fineschi S, eds) Academic Press, The Hague, 59-74

Endler JA (1977) Geographical Variation, Speciation, and Clines. Princeton University Press, Princeton, NJ

Epperson BK, Clegg MT (1986) Spatialautocorrelation analysis of flower color polymorphisms within substructured populations of morning glory (Ipomoea purpurea). Am Nat 128, 840-858

Epperson BK, Allard RW (1989) Spatial autocorrelation analysis of the distribution of geno- types within populations of lodgepole pine. Genetics 121, 369-377

Gottlieb LD (1981) Electrophoretic evidence and plant populations. In: Progress in Phytochemistry, (Reingold J, Harborne JB, Swain T, eds), Pergamon Press, New York, vol 8, 1-46

Guttman LI, Weigt LA (1989) Electrophoretic evidence of relationships among Quercus (oaks) of eastern North America. Can $J$ Bot $67,339-351$

Hampe CL (1984) A description of species composition, population structures, and spatial patterns in a Missouri oak-hickory forest. MS thesis, Univ Missouri, St Louis

Hamrick JL, Godt MJ (1989) Allozyme diversity in plant species. In: Plant Population Genetics Breeding, and Genetic Resources (Brown AHD, Clegg MT, Kahler AL, Weir BS, eds) Sinauer Associates, Sunderland, MA, 43-63

Haufler $\mathrm{CH}$ (1985) Enzyme variability and modes of evolution in Bommeria (Ptridaceae). Syst Bot 10, 92-104

Heywood JS (1991) Spatial analysis of genetic variation in plant populations. Annu Rev Ecol Syst 22, 335-355

Linhart YBJ, Mitton B, Sturgeon KB, Davis ML (1981) Genetic variation in space and time in a population of ponderosa pine. Heredity 46 , 407-426

Loveless MD, Hamrick JL (1984) Ecological determinants of genetic structure in plant populations. Annu Rev Ecol Syst 15, 65-95

Manos PS, Fairbrothers DE (1987) Allozyme variation in populations of six northeastern American red oaks (Fagaceae: Quercus subg Erythrobalanus). Syst Bot 12, 365-373

Mitton JB (1983) Conifers. In: Isozymes in Plant Genetics and Breeding, Part B (Tanksley S, Orton T, eds) Elsevier, Amsterdam, 443-472

Mitton JB, Linhart YB, Hamrick JL, Beckman JH (1977) Observations on the genetic structure and mating system of ponderosa pine in the Colorado Front Range. Theor Appl Genet 51, 5-13

Nei M (1973) Analysis of genetic diversity in subdivided populations. Proc Natl Acad Sci USA 70, 3321-3323

Nei M (1978) Estimation of average heterozygosity and genetic distance from a small number of individuals. Genetics $89,583-590$ 
Schlarbaum SE, Adams RP, Bagley WT, Wayne WJ (1982) Postglacial migration pathways of Quercus rubra L, northern red oak, as indicated by regional genetic variation patterns. Silvae Genet 31, 150-158

Shopmeyer CS (1974) Seeds of Woody Plants in the United States. USDA For Serv Agric Handb 450

Schnabel A, Hamrick JL (1990a) Comparative analysis of population genetic structure in Quercus macrocarpa and $Q$ gambelii (Fagaceae). Syst Bot 15, 240-251

Schnabel A, Hamrick JL (1990b) Organization of genetic diversity within and among populations of Gleditsia triacanthos (Leguminosae). Am J Bot 77, 1060-1069

Schwarzmann JF, Gerhold HD (1991) Genetic structure and mating system of northern red oak (Quercus rubra L) in Pennsylvania. For Sci 37, 1376-1389

Slatkin M (1973) Gene flow and selection in a cline. Genetics 75, 733-756

Slatkin M, Arter HE (1991) Spatial autocorrelation analysis as inferential tool in population genetics. Am Nat 138, 499-517

Sokal RR, Oden NL (1978) Spatial autocorrelation in biology. I. Methodology. Biol J Linn Soc 10, 199-228
Soltis DE, Haufler CH, Darrow DC, Gastony GJ (1983) Starch-gel electrophoresis of ferns: a compilation of grinding buffers, gel and electrode buffers, and staining schedules. Am Fern J 73, 9-27

Sork VL (1984) Examination of seed dispersal and survival in red oak, Quercus rubra, using metal-tagged acorns. Ecology 65, 1020-7022

Sork VL, Idol J, Noyes J, Wiener E (1992) Mating systems in three species of Missouri oaks, Quercus alba, $Q$ rubra and $Q$ velutina. Am J Bot 79 (6, suppl) 69

Sork VL, Stowe K, Hochwender C (1993) Evidence for local adaptation in closely adjacent subpopulations of northern red oak (Quercus rubra $L$ ) expressed as resistance to leaf herbivores. Am Nat (in press)

Swofford DL, Selander RB (1981) BIOSYS-1: a Fortran program for the comprehensive analysis of electrophoretic data in population genetics and systematics. $J$ Hered $72,281-283$

Wright $S$ (1943) Isolation by distance. Genetics 28, 114-138

Wright $S$ (1951) The genetical structure of populations. Ann Eugen 15, 323-354

Wright $S$ (1965) The interpretation of population structure by $F$-statistics with special regard to systems of mating. Evolution 19, 395-420 